International Journal of Environment, Agriculture and Biotechnology
Vol-6, Issue-3; May-Jun, 2021
J Journal Home Page Available: https://ijeab.com/
Journal DOI: $10.22161 /$ ijeab

Article

Peer-Reviewed Journal

\title{
Mini review of parasitoids collected in the Cerrado Biome in Brazil
}

\author{
Carlos Henrique Marchiori
}

Department of Biological Sciences, CHM, Instituto Federal Goiano, Brazil

Received: 09 May 2021; Received in revised form: 09 Jun 2021; Accepted: 19 Jun 2021; Available online: 27 Jun 2021

(C)2021 The Author(s). Published by Infogain Publication. This is an open access article under the CC BY license

(https://creativecommons.org/licenses/by/4.0/).

\begin{abstract}
The climate is predominantly hot with a rainy and a dry season. Second only to the Amazon, the Cerrado occupies an area of more than 2 million $\mathrm{km}$, corresponding to about $25 \%$ of the national territory. It is not only the second largest ecosystem in Brazil, but also in all South America. It is known as such in our country, but in other parts of the world it occurs under the name of savannas, which are characterized by vegetation with low trees, spaced shrubs, and grasses. For the elaboration of this mini review, which consists of the construction of a bibliographic summary of the main groups of parasitoids of the Order Hymenoptera, with an emphasis on the hymenopterans parasitoids collected in the Cerrado Biome (savanna). A bibliographic search was carried out that contained papers published from 2001 to June 2021 on the quantitative aspects of Superfamilies, Families, Subfamilies, Genera and Species. The mini review was carried out from February to June 2021. Parasitoids are often called parasites, but the term parasitoid is more technically correct. By definition, insect parasitoids have a free-living adult stage and an immature life stage that develops on or within an insect host and ultimately kills it. After feeding on host body fluids and organs, most parasitoids leave their hosts to pupate or emerge as adults. Parasitoids have a free-living adult stage and an immature life stage that develops on or within an insect host and ultimately kills it. They are effective control agents in pest population.
\end{abstract}

Keywords - Agriculture, Biological control, Biological Sciences, Insect pests.

\section{CERRADO}

It is known as such in our country, but in other parts of the world, it occurs under the name of savannas, which are characterized by vegetation with low trees, spaced shrubs, and grasses. The climate is predominantly hot with a rainy and a dry season. Second only to the Amazon, the Cerrado occupies an area of more than 2 million $\mathrm{km}$, corresponding to about $25 \%$ of the national territory. It is not only the second largest ecosystem in Brazil, but also in all South America. In the Cerrado domain, the rivers that form the main hydrographic basins in the country are born. They are: Parnaíba, Paraguay, Paraná, Tocantins-Araguaia, São Francisco, and Amazônia. Paraguay and Paraná join the Uruguay River and form the La Plata basin, which is of great economic importance for Brazil and the bordering countries. In its area there are also three large aquifers: Guarani, Bambuí and Urucuia. The Cerrado is considered a global hotspot - an area that is home to great biological diversity and endemic species, that is, they are not found anywhere else in the world (Costa 2019).

It is estimated to have more than 6,000 species of trees and 800 of birds. Approximately $40 \%$ of woody vegetation species and about $50 \%$ of bees are endemic species. Regarding insects, there are more than 14 thousand species, representing $47 \%$ of the insect diversity in Brazil. Research claim that $20 \%$ of native and endemic species no longer occur in protected areas and that at least 137 species of fauna present in the Cerrado are threatened with extinction. After the Atlantic Forest, the Cerrado was the Brazilian biome that received the most exploitation by human activities. Agricultural and livestock expansion is largely responsible for this occupation, along with the use of firewood to produce charcoal (Costa 2019). 
The Cerrado is one of the six Brazilian biomes, concentrated mainly in the Central Plateau, and is present in the states of Goiás, Tocantins, Mato Grosso, Mato Grosso do Sul, Minas Gerais, Bahia, Maranhão, Piauí, Rondônia, Paraná, São Paulo, and Federal District (Costa 2019).

Despite the unique characteristics of biodiversity, the Cerrado, along with the Caatinga, is the least protected area by the government. This biome has $8.21 \%$ of its territory legally protected by conservation units; of this total, $2.85 \%$ are full protection conservation units, in which only indirect uses are allowed; and $5.36 \%$ of sustainable use conservation units, in which the use of natural resources is compatible with nature conservation (Costa 2019).

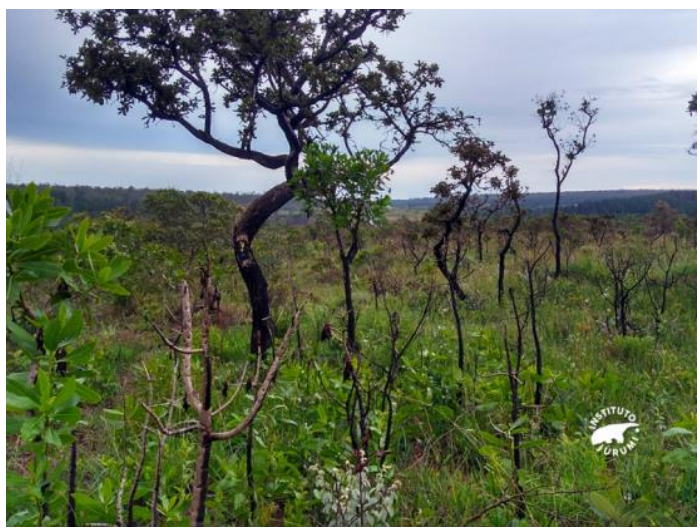

Fig.1: General aspect of the Cerrado.

\section{PARASITOIDS}

Parasitoids are often called parasites, but the term parasitoid is more technically correct. By definition, insect parasitoids have a free-living adult stage and an immature life stage that develops on or within an insect host and ultimately kills it. After feeding on host body fluids and organs, most parasitoids leave their hosts to pupate or emerge as adults.

Parasitoids have a free-living adult stage and an immature life stage that develops on or within an insect host and ultimately kills it. They are effective control agents in pest population (Gibb 2015).

Most beneficial insect parasitoids are wasps or flies, although other insects may have life stages that are parasitoids as well. Parasitoids usually complete their life cycles much more quickly and increase their numbers faster than predators, even though a parasitized host does not die as quickly as those eaten by predators (Gibb 2015).

Parasitoids are often the most effective natural enemy of pest insects, even though they may not be readily visible.
Sometimes pest populations increase after pesticides are applied. This can happen when a chemical insecticide poisons the parasitoids before they can kill the pest insect host. Once free of the natural parasitoids (Figure 2), the pest insects are then free to increase in number (Gibb 2015).

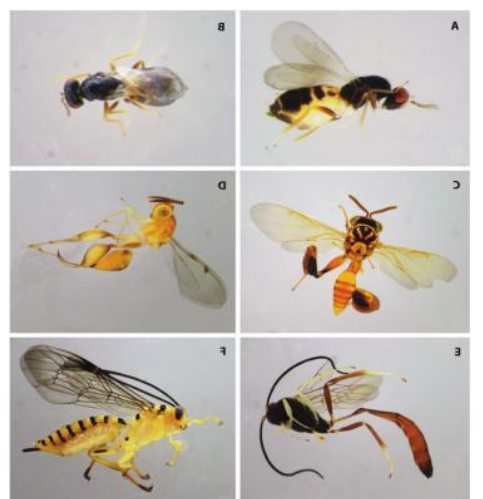

Fig.2: Parasitoids of Mechanitis menapis mantineus: $A-B$ (Eulophidae), from huevos; $C$-D (Chalcididae), from larvae; E (Ichneumonidae) and $F$ (Braconidae), from pupa. Parasitoids of Mechanitis menapis mantineus: $A-B$ (Eulophidae), from eggs; $C$-D (Chalcididae), of larvae; $E$ (Ichneumonidae) and $F$ (Braconidae), from pupa. Source: Paola Santacruz, Science Museum · Research Master of Science. https://www.researchgate.net/profile/PaolaSantacruz-3

\section{METHODS}

For the elaboration of this mini review, which consists of the construction of a bibliographic summary of the main groups of parasitoids of the Order Hymenoptera, with an emphasis on the hymenopterans parasitoids collected in the Cerrado Biome. A bibliographic search was carried out that contained papers published from 2001 to June 2021 on the quantitative aspects of Superfamily, Family, Subfamily, Genera and Species. The mini review was carried out from February to July 2021 using the Online Electronic Scientific Library (Scielo) and Internet (Google) in Goiânia, Goiás, Midwest region. 


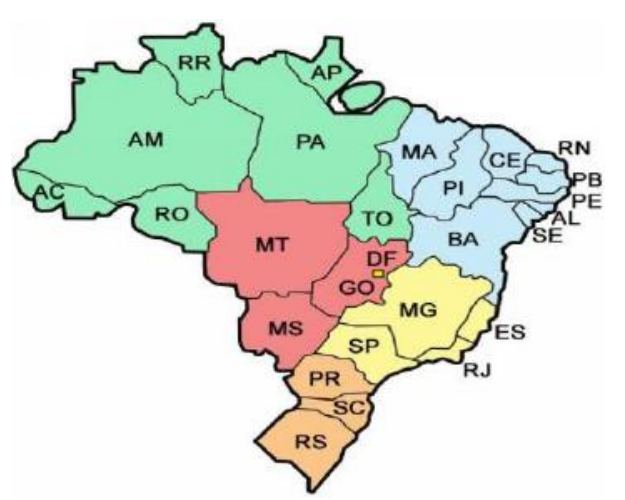

Fig.3: Map of Brazil, Goiás (GO), Midwest region (red color). Source:

https://br.pinterest.com/pin/576320083551631769/

\section{STUDIES PERFORMED}

\section{Study 1}

The objective of this research work was to identify the genera of Braconidae collected in a remnant area of native forest located in Itumbiara County, State of Goiás, Brazil, using Malaise traps (Figure 4). Twenty-four samplings were performed from January to December 200. From these collections, 49 specimens from 19 different genera and 10 subfamilies of Braconidae were obtained. The subfamily Doryctinae had the highest diversity of genera. The number of specimens obtained was low considering the collection period. Chelonus was the most abundant genus comprising $34.7 \%$ of the specimens collected. Most specimens were obtained in the months of March and June, with $20.4 \%$ and $24.5 \%$ occurrence frequency, respectively. These results contribute to the knowledge of entomofauna occurring in the Itumbiara region, southern Goiás state, Brazil (Marchiori 2014).

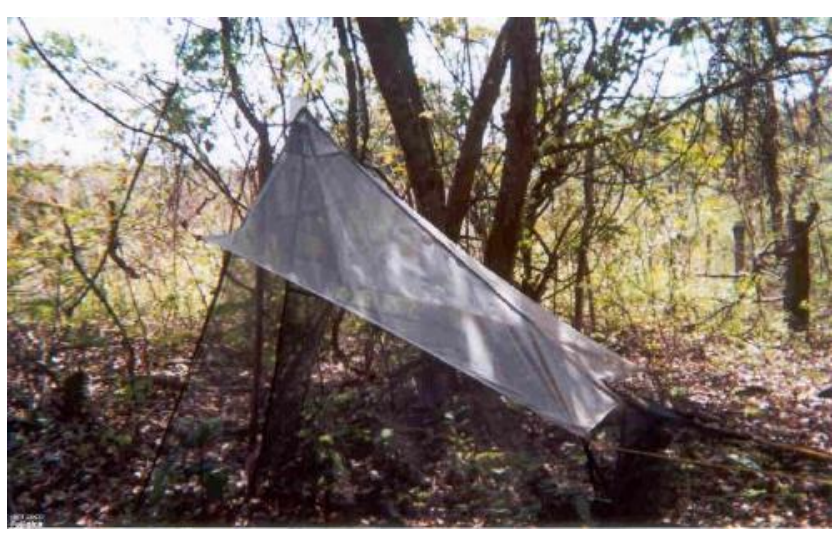

Fig.4: Malaise traps

\section{Study 2}

The objective of this study was to investigate the families of the Hymenoptera parasitoids collected in areas of native forest, using Malaise traps and Moericke traps in western Minas Gerais and southern Goiás. The experiment was conducted at the Faculty of Agronomy Farm in southern of Goiás and the western of Minas Gerais in Alvorada Farm in the period February to October 2002. Sampling was weekly, with 10 Moericke traps and 3 Malaise. A total of 15827 specimens of parasitoids distributed in 8 superfamilies and 21 families were collected, of which 10435 in Malaise traps and 5400 in the Moericke traps (Figure 5).

A total of 9540 specimens were collected in western Minas Gerais with and 6287 in southern Goiás. The most abundant families were Ichneumonidae with 4562 and Braconidae with 2532. The Ichneumonidae was the most frequent family collected in the Moericke traps. Also, in the Malaise traps, the family Ichneumonidae was the most frequently found. The superfamily Chalcidoidea presented the highest diversity of families (10 families) in both trap types (Marchiori et al. 2002).

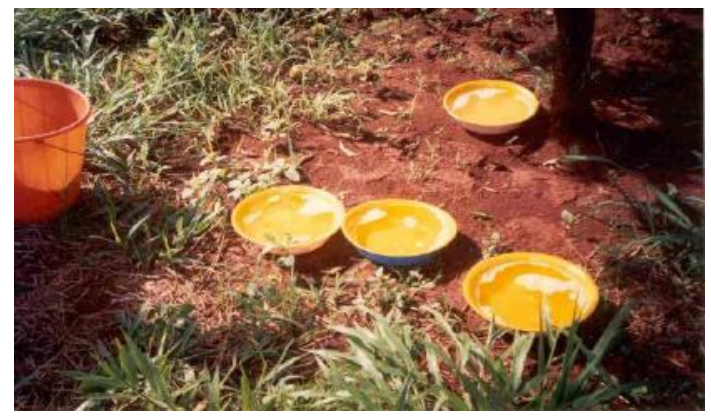

Fig.5: Moericke traps

\section{Study 3.}

With this work, it is intended to get acquainted with Eucoilinae collected in a remnant of thick wood by the trap "Malaise" in Itumbiara, Goiás. The trap "Malaise" captures the insects by interceptation. During the period from February to September 2000, 20 specimens of the subfamily Eucoilinae (Hymenoptera: Figitidae) were collected, of which 1 specimen of Dicerataspis sp., 3 specimens of Dettmeria sp., 1 specimen of Odonteucoila sp., 1 specimen of Paraganaspis egeria (Diaz, Gallardo \& Wash), 10 specimens of Steleucoela sp., 1 specimen of Trybliographa sp. and 2 specimens of Zaeucoila unicarinata Ashmead. Steleucoela sp. was the most abundant species with $50.0 \%$. The number of females $(35.0 \%)$ was lower than that of males $(65.0 \%)$ in an approximate proportion of $2: 1$. This work registers the first occurrence of Dicerataspis sp., Trybliographa sp., and 
Zaeucoila unicarinata to the State of Goiás and Steleucoela sp. to Brazil. Steleucoela sp. (Marchiori et al. 2001)

\section{Study 4.}

794 specimens of hymenopterans were sampled parasitoids distributed in seven superfamilies and 27 families. The most predominant Family of individuals was Ichneumonidae with $21.9 \%$ followed of Ceraphronidae with $17.4 \%$ of the total samples. At Malaise traps were the ones that captured the biggest number of families and individuals, 26 and 541 respectively. The family that was most captured by these traps was Ceraphronidae, with $17.0 \%$ of the individuals collected. The Moericke and Sweep traps captured a close number of families, 13 and 14 respectively, despite the large difference in the number of individuals, 183 and 70, this difference can be justified by differences in the sampling effort of each method. At Moericke traps have not captured an exclusive family, on the other hand, sweeping the vegetation was the only method that collected the Pelicinidae family. In both methods, the family Ichneumonidae was the most sampled. Being a pioneering study involving parasitic collection in the southwest region of the state of Goias, and the results of the collections having been carried out in a short space of time (20 days), the number of copies and families collected can be considered quite representative, considering the small size of the sampled fragment (Morais et al. 2011).

\section{Study 5}

The aim of this study was to know the parasitoid hymenopteran fauna in an agricultural area. The survey was carried out between May 2003 and June 2004 in an area of 24.2 hectare located in the municipality of Rio Claro, SP, Brazil during this period, the cultivation of sorghum, corn, beans and wheat was carried out in a rotation system under no-tillage. Collections were carried out every two weeks, using 17 Moericke traps (Souza et al. 2006).

A total of 5,308 parasitoid hymenopteran were collected belonging to 22 families distributed in 8 superfamilies. The most collected superfamilies in this survey were Chalcidoidea and Platygastroidea with $60.08 \%$ and $21.65 \%$, respectively, representing $81.73 \%$ of the total collected. The most abundant families were Mymaridae (30.88\%), Encyrtidae (19.05\%) (Chalcidoidea), Scelionidae (14.96\%) and Platygastridae (6.69\%) (Platygastroidea). The remaining eighteen families presented relative frequencies, in relation to the total of collected parasitoids, inferior to 5\%. The other superfamilies found had a relative frequency lower than $5 \%$, being Ceraphronoidea $(4.52 \%)$, Proctotrupoidea
(4.45\%), Ichneumonoidea (4.09\%), Cynipoidea (3.01), Chrysidoidea (1.92\%) and Evanioidea (0.28\%) (Souza et al. 2006).

\section{Study 6.}

This work presents a survey of the entomofauna associated with the fruits of the bacupari (Salacia crassifolia) (Ippocrateaceae family) in the cerrados of Goiás. The fruits were collected from September 1995 to December 1999, at the time of fruiting (Rocha et al. 2001).

A total of 1,090 insects were obtained from 2,898 fruits in 11 municipalities of the State of Goiás. The flies collected were from the families Tephritidae (54.22\%), Lonchaeidae (6.60\%), Muscidae $(1.01 \%)$ and Oititidae (1.01\%). Among the Tephrididae the species collected were Anastrepha fraterculus (Wiedemann), Anastrepha obliqua ((Macquart), Anastrepha serpentina (Wiedemann), Anastrepha sororcula Zucchi and Anastrepha sp. (new species). Insects of the Lonchaeidae family represented by Neosilba spp. Another species of lesser occurrence was Atherigona orientalis Schiner (Diptera: Muscidae). A total of 405 parasitoids were collected from 3,474 fruit fly pupae grouped in the Braconidae (390), Figitidae (12) and Pteromalidae (03) families. The most frequent species was Doryctobracon sp., with a parasitism rate of $8.78 \%$ (Rocha et al. 2001).

\section{Study 7.}

This work aimed to carry out a survey of winged aphids and parasitoids associated with wheat crop in a Cerrado area in the state of Minas Gerais. Rhopalosiphum padi (Linnaeus), Sitobion avenae (Fabricius), Rhopalosiphum maidis (Fitch) were the most collected aphid species during the three years of study. The largest aphid population observed in 2014 in Uberaba, when compared to 2013 and 2015 , may be related to the lower rainfall that occurred that year, during wheat cultivation. Six species of parasitoids associated with wheat aphids were recorded, with Aphidius colemani Viereck (Hymenoptera: Braconidae, Aphidiinae) being the most collected species during the two years of study (Júnior et al. 2021).

\section{Study 8.}

This paper presents a survey of parasitic Hymenoptera obtained from fruits of Ilex affinis Gardner (Aquifoliaceae) collected in area of the Brazilian savannah (cerrado) in São Paulo State, Brazil. Green fruits of I. affinis were collected in a residual area of Brazilian savanna located at Fazenda Itaúna in Descalvado County, São Paulo State, Brazil, and maintained in plastic containers covered with synthetic gauze and daily observed until putrefaction. Eighty-eight seeds, from 50 fruits, were dissectedm under 
stereomicroscope and data of the presence of insects in its interior recorded (Perioto et al. 2009).

From the fruits were reared 21 specimens of Eurytomidae (Hymenoptera): 20 females of Prodecatoma juliae sp. nov. and one male of Sycophila sp., 20 females and 10 males of Galeopsomyia itauna sp. nov. (Hymenoptera, Eulophidae) and two males of a not identified species of Doryctinae (Hymenoptera, Braconidae). In the 50 dissected seeds fruit were found 88 seeds (1.8 seed/fruit), 63 (71.6\%) infested by chalcids from which $8(12.7 \%)$ were attacked by Galeopsomyia itauna sp. nov., 55 by (87.3\%) Prodecatoma juliae sp. nov. and one (1.6\%) by Sycophila sp. Records in the literature show that immature stages of Prodecatoma and Sycophila are seed infesting chalcids; probably Galeopsomyia is a infesting parasitoid of the seed and the ecological function of the Doryctinae was not established. Records in the literature show that immature stages of Prodecatoma and Sycophila are seed infesting chalcids; probably Galeopsomyia is a infesting parasitoid of the seed and the ecological function of the Doryctinae was not established (Perioto et al. 2009).

\section{Study 10.}

Accordingly, aim of this study was to conduct a broadscale assessment of the faunal composition of parasitoid Hymenoptera of the Parque Nacional Serra da Canastra. Sampling was carried out between September 2009 and October 2010 and totaled 45 samples sweepings from all four sites. Each monthly sample was a result of 15 minutes of simultaneous collection effort, by four people (total excluding time for stops to removal of collected material). The technique was applied randomly to vegetation from ground level to a height of approximately two meters. During data collection, the insects captured were transferred to killing bags containing cotton pads soaked in ethyl acetate, to fix the material collected (Pádua et al. 2014).

Eight superfamilies and 24 families. Three Pimplinae genera were also identified. Neotheronia, Pimpla and Zonopimpla were genera of pimplineds collected in this study, through the sweeping technique. Eulophidae, Braconidae, Platygastridae, Pteromalidae and Encyrtidae together were the most abundant families, giving $73 \%$ of the total sample (4,743 exemplars). The abundance of Braconidae was higher than the other families for six months of the collecting, while Eulophidae was highest for four months, already Platygastridae and Pteromalidae for one month each. Eulophidae, Braconidae, Platygastridae and Ichneumonidae occurred in all samples by month (Pádua et al. 2014).

\section{Study 11.}

The objective of this study was to verify whether fruit flies present seasonality in three contiguous orchards, relating these data to host phenology and to parasitoids. The study was conducted, during 2002 and 2003, in Monte Alegre do Sul, SP. The experiments were carried out in three orchards: a collection of guava progenies (Psidium guajava L.); a collection of loquat cultivars [Eriobotrya japonica (Thunb.) Lindl.]; and a collection of peach [Prunus persica (L.) Batsch] and nectarine (P. persica var. nucipersica) cultivars (Souza Filho et al. 2009).

No phytosanitary treatments were performed in the orchards during the assays. The fruits were taken to the laboratory and placed individually in $500 \mathrm{~mL}$ capacity plastic pots containing sand + vermiculite covered with voile fabric held in place with elastic tape. Each fruit remained in the plastic pot for approximately 20 days until the emergence of flies and/or parasitoids (Souza Filho et al. 2009).

Ten parasitoid species were collected. The braconids belonged to five species - Asobara anastrephae (Muesebeck), Doryctobracon areolatus (Szépligeti), Doryctobracon brasiliensis (Szépligeti), Opius bellus Gahan, and Utetes anastrephae (Viereck). Doryctobracon areolatus, D. brasiliensis, and $U$. anastrephae can be highlighted as the most important parasitoids in the State of São Paulo, parasitizing fly larvae on practically all known host plants. Figitids were retrieved from larvae attacking only guava - Aganaspis pelleranoi (Brèthes), Dicerataspis grenadensis Ashmead, Lopheucoila anastrephae (Rhower), Leptopilina boulardi (Barbotin, Carlton and Kelner-Pillaut), and Trybliographa infuscata Diaz, Gallardo and Uchôa. Most braconid species developed on tephritid larvae in peach in 2002, but only Doryctobracon species $-D$. areolatus and D. brasiliensis were also obtained in 2003 (Souza Filho et al. 2009).

\section{Study 12.}

The purpose of this paper is to report the parasitoids of dipterans in poultry farms in Brazil. The experiment was carried out in two poultry farms in the Midwest Region in Brazilian territory. Feces were removed from the farm sheds placed in 10 basins to be transported to the laboratory for removal of pupae. In the laboratory, pupae were obtained. The pupae were removed and placed on absorbent paper for drying and later individualized in glass capsules for the emergence of adult flies or parasitoids. The collections were carried out monthly from January to December 2007. From 10,608 pupae of dipteran collected 816 parasitoids emerged from 540 pupae (Marchiori 2021). 
The total percentage of parasitism found in this study was $5.1 \%(540 / 10.608)$ and species: Muscidifurax raptorellus Kogan \& Legner, with (5/504) 1.0\%, Nasonia vitripennis (Walker) (Hymenoptera: Pteromalidae) (10/504)2.0\%, Pachycrepoideus vindemmiae (Rondani) (Hymenoptera: Pteromalidae) (367/504) 93.9\%, Spalangia cameroni Perkins (Hymenoptera: Pteromalidae) (12/504) 2.4\%, Spalangia drosophilae Ashmead (Hymenoptera: Pteromalidae) (2/504) 0.4\%, Spalangia endius Walker (Hymenoptera: Pteromalidae) (77/504) 15.2\%, Spalangia nigra Latrielle, (Hymenoptera: Pteromalidae) (17/504) $3.3 \%$, Spalangia nigroaenea Curtis (Hymenoptera: Pteromalidae) (8/504) 1.6\%, Spalangia sp. (Hymenoptera: Pteromalidae) (15/504) $3.0 \%$ and Tachinaephagus zealandicus (Ashmead, 1904) (10/504) $2.0 \%$ (Encyrtidae) (Marchiori 2021).

\section{Study 13}

The objective of this study was to verify the parasitoid species of Musca domestica L. (Diptera: Muscidae) and their biological characteristics collected in an urban area in Brazil. This experiment was conducted in the urban area near Botafogo River, Goiânia, Goiás, Brazil. Parasitoids were collected by exposing larvae of $M$. domestica and its breeding substrate (bovine beef liver) outdoors, in containers filled with sand that were placed next to garbage containers. The parasitoids were collected by using four traps. The following items were used as baits: human feces, cattle kidneys, cattle liver and fish which were placed inside the cans, over a layer of earth. To obtain the parasitoids, the contents of the traps were placed in plastic containers with a layer of sand for use as a substrate for transformation of the larvae into pupae (Marchiori 2019).

From March to September 2015, 35 specimens of parasitoids were collected. The species of Hymenoptera collected and their frequency were: Hemencyrtus sp. (Encyrtidae), with 1 specime, Tachinobia sp. (Eulophidae) with 1 specime, Pachycrepoideus vindemmiae (Rondani) with 26 specimens and Spalangia spp. (Pteromalidae) with 7 specimens (Marchiori 2019).

\section{Study 14.}

This work aimed to evaluate the frequency and distribution of natural enemies of Spodoptera frugiperda (Smith, 1797) (Lepidoptera: Noctuidae) from artificial infestation with pest postures in maize crops, in order to associate the presence of biological control agents to the different stages of development of the host insect. The experiment was carried out in the summer crop, in a cerrado area, in Sete Lagoas, MG. At each collection, 20 plants from each plot were randomly covered with a plastic bag and then cut at the base, thus allowing the collection of all insects present on the leaves. Plants were collected in the morning, starting at eight o'clock, and then taken to the laboratory (Figueiredo et al. 2006).

Each plant had its leaves detached and evaluated for the presence of insects. The eggs and caterpillars of $S$. frugiperda were placed in $50 \mathrm{ml}$ cups containing artificial diet; the other insects present in the plants were placed in a $70 \%$ alcohol solution. Natural enemies, coming from the different stages of pest development, were separated, and grouped according to their entomological classification (Figueiredo et al. 2006).

Among the parasitoids obtained from the parasitized caterpillars, there was a predominance of species of the order Hymenoptera. The occurrence of the egg/caterpillar parasitoid Chelonus insularis Cresson (Braconidae) and of the caterpillar parasitoids Eiphosoma laphygmae Costa Lima (Ichneumonidae), Campoletis flavicincta (Ashmead) (Ichneumonidae), Cotesia marginusonidae (Braconidae) (Braspinus sonris (Cres) Fabricius) (Ichneumonidae) and Exasticolus fuscicornis (Cameron) (Braconidae). Archytas incertus (Macquart) (Diptera: Tachinidae) was the only representative of this order. Among the parasitoids, Chelonus insularis (Cresson) (Hymenoptera: Braconidae), present in all collections, accounted for $91 \%$ of the parasitism (Figueiredo et al. 2006).

\section{Study 15.}

The present study aimed to analyze the parasitoid insects and their interactions with endophytic insects in Stryphnodendron adstringens (Family: Fabaceae) (Mart.) Coville fruits in an area of Cerrado in southwestern Minas Gerais, located in the vicinity of Serra Nacional Park of Canastra. This Park is the second largest conservation unit in the Southeast, located in the southwestern portion of the state of Minas Gerais, between the municipalities of São Roque de Minas, Delfinópolis, Sacramento, São João Batista do Glória, Capitólio and Vargem Bonita. The fruits were randomly collected from one or several plant specimens, at heights distinct from the crown and at different stages of development. Both immature but developed fruits, ripe and still closed fruits and ripe ones starting to dehiscence were collected, selecting those with traces of insect attack. To remove fruits from the upper regions of the crown, long-stemmed pruning shears and pruning shears were used (6 meters) (Silva and Zampieron 2016).

From the eight collections carried out, from March to October 2013, a total of 210 fruits of S. adstringens were obtained. The order Hymenoptera, second most abundant, was represented by 11 families, which are mostly parasitoids of Coleoptera or Lepidoptera, and some phytophagous specimens. The biology of these parasitoids 
associated with seed predators is still poorly understood, with the main families being: Pteromalidae, Eulophidae (Chalcidoidea) and Braconidae (Ichneumonoidea). As for the families of the order Hymenoptera, the best represented was Braconidae (49.25\%), with emphasis on the genus Allorhogas Gahan, included in Doryctinae. Of the Braconidae considered parasitoids, the following genera were associated with lepidopterans: Pseudophanerotoma Zetel, Chelonus Panzer, Hormius Nees, Apanteles Foerster and Clinocentrus Haliday (Silva and Zampieron 2016).

\section{Study 16.}

The aims of this study were to characterize galls of three species on this genus, Copaifera depilis Dwyer, Copaifera luetzelburgii Harms and Copaifera sabulicola Costa \& Queiroz (Leguminosae), which occur sympatrically in Western Bahia and compare their abundance. This municipality is located in the Cerrado Biome and presents two well defined seasons, a dry and rainy. The collections were carried out from December 2012 to January 2013 (Santos et al. 2018).

In the three Copaifera species, a total of 23 gall morphotypes were obtained, 9 morphotypes found on $C$. sabulicola, 7 on $C$. luetzelburgii and 7 on $C$. depilis. In the present study, we observed that five morphotypes were induced by Cecidomyiids and the gallers of 18 morphotypes cannot be determined, because the gall samples were collected occupied by parasitoids or without dweller. Cecidomyiidae are the most important galler in all zoogeographic regions. Microhimenopterans identified represents possibly parasitoids, natural enemy of Cecidomyiidae (Hymenoptera, except for ants (Formicidae, predator), which were found on abandoned galls, being considered in this study as a successor for Copaifera langsdorffii Desf. (Fabaceae), Oliveira et al. (2013) pointed that the level of (Santos et al. 2018).

\section{Study 17.}

The main purposes hereof were: 1) to correlate climatic factors (specify rainfall, temperature, and relative humidity) with the incidence of fruit flies and their parasitoids under the conditions of the region Cariri, Ceará; 2) to estimate the fruit fly species infestation rates in guavas, and 3) to determine the natural parasitism rates and the frequency of native parasitoids. The guava sampling was performed every week, randomly, and according to the fruit development period, from September 2013, to August, 2014, collecting every fruit of the trees, totalizing 167 trees in the whole orchard

(Azevedo et al. 2018)
During the study period, 1184 fruit fly pupae were collected from 667 fruits gathered on the orchard located in the city of Barbalha (CE). Five fruit fly species were obtained: Anastrepha zenildae (Zucchi, 1979) (62.7\%), Anastrepha sororcula (Zucchi, 1979) (27.3\%), Anastrepha obliqua (Macquart, 1933) (19\%), Anastrepha antunesi (Lima, 1938) (0.6\%), and Ceratitis capitata (Wiedemann, 1824) (26.2\%). Besides fruit flies, four parasitoids species were found: Doryctobracon areolatus (Szépligeti, 1911) (75\%), Asobara anastrephae (Muesebeck, 1958) (18.4\%), Utetes anastrephae (Viereck, 1913) (5.3\%), and Opius bellus (Gahan, 1930) (0.6\%), all belonging to the Family Braconidae (Azevedo et al. 2018).

\section{Study 18.}

This work aimed to determine the richness of fruit flies species, their respective host plants and their parasitoids in municipalities in the northern region of Mato Grosso. Fruits from 34 plant species were collected from July 2016 to November 2017. The collected fruits were placed in plastic containers to observe the emergence of fruit flies and parasitoids. Samples of 34 plant species were collected, grouped into 15 different botanical families (Silva et al. 2019).

Of these, 12 species were registered as host plants of fruit flies, belonging to the families Anacardiaceae, Malpighiaceae, Myrtaceae and Oxalidaceae. Fruits were collected according to field availability, which influenced the diversity of plant species sampled in each municipality. Myrtaceae was the family with the highest number of species sampled (9), followed by Anacardiaceae (4) and Rutaceae (4). From the collected samples, 2,709 specimens of fruit flies (five species) and 179 specimens of parasitoids (three species) were obtained (Silva et al. 2019).

Five tephritid species were recorded: Anastrepha fraterculus (Wiedemann), A. obliqua (Macquart), $A$. sororcula Zucchi, A. striata Schiner and Ceratitis capitata (Wiedemann). In this study three species of parasitoids were recorded: D. areolatus, Utetes anastrephae Viereck and Asobara anastrephae (Muesebeck), all obtained in the municipality of Nova Guarita (Silva et al. 2019).

In Sinop, only $D$. areolatus and $U$. anastrephae were obtained: D. areolatus was obtained from samples of Averrhoa carambola (Oxalidaceae), Eugenia pyriformis (Myrtaceae), Plinia cauliflora (Myrtaceae), Psidium cattleianum (Myrtaceae), Psidium guajava (Myrtaceae) and Spondias purpurea (Anacardiaceae). Association of the parasitoid D. areolatus with A. striata in P. cattleianum and $P$. guajava fruits, and with $C$. capitata in $A$. carambola fruits were verified. The parasitoid $U$. anastrephae was obtained by collecting fruits of $A$. 
carambola, E. pyriformis, P. cauliflora and S. purpurea. Association of $U$. anastrephae with $A$. obliqua in $S$. purpurea fruits was verified (Silva et al. 2019).

\section{Study 19.}

The objective of this study was to records the parasitoid Gnathopleura semirufa (Brullé 1846) parasitizing parasitizing flies of the Family Sarcophagidae in Brasil. The study on pitfall traps was also conducted on the campus of the Agronomy School in Itumbiara, Goiás, between January and November 2005. Six traps were used, with separations of two meters between each other, placed randomly. The bait was replaced every 15 days. The pupae that were found in the bait were separated out by means of the floatation method. These were then individually packed in gelatin capsules until the parasitoids emerged (Marchiori 2014).

Collected from 305 pupae Oxysarcodexia thornax (Walker) (Diptera: Sarcophagidae), 143 Peckia chrysostoma (Wiedemann) (Diptera: Sarcophagidae) and 182 of Sarcodexia lambens (Wiedemann) (Diptera: Sarcophagidae) that emerged 75, 51 and 31 parasitoid species Gnathopleura semirufa (Brullé, 1846) (Hymenoptera: Braconidae) respectively. The total percentage parasitism observed was around $25.0 \%$ (Marchiori 2014).

The host showing the highest percentage parasitism was $P$. chrysosotoma in cattle liver, and this was probably due to the seasonality factor presented by this species. The percentage of parasitism observed in $O$. thornax, $P$. chrysosotoma and S. lambens was $24.6 \%, 35.7 \%$ and $17.0 \%$, respectively. The total percentage parasitism observed was around $25.0 \%$. The host showing the highest percentage parasitism was $P$. chrysosotoma in cattle liver and this was probably due to the seasonality factor presented by this species. The percentage of parasitism observed in $O$. thornax, $P$. chrysosotoma and S. lambens was $24.6 \%, 35.7 \%$ and $17.0 \%$, respectively (Marchiori 2014).

\section{Study 20}

This study had the objective of determining the species of parasitoids of dipterous insects that were present in bovine feces collected in Goiânia Goiás, Brazil. Every fortnight, 10 plates of fecal cake produced from fresh bovine feces that were collected immediately after defecation in pastures and in corrals. The feces remained exposed (a total of 10 plastic basins, five in the pastures and five in the corrals) for 15 days. After this period, the feces were taken to the laboratory for extraction of pupae by means of the flotation method. The pupae were removed with the aid of a sieve; they were counted and individually stored in gelatin capsules until the flies and/or parasitoids emerged (Marchiori et al. 2013).

We collected 359 pupae of Diptera, of which 23 parasitoids emerged. The most frequently observed species in Goiânia was Aleochara notula Erichson, 1839 (Coleoptera: Staphylinidae), accounting for $26.1 \%$. The overall percentage of parasitism contacted was $6.4 \%$. Nasonia vitripennis (Walker, 1836) (Hymenoptera: Pteromalidae) was the species in the central region that presented the highest percentage parasitism, with $9.8 \%$ (Marchiori et al. 2013).

In relation to the attraction of parasitoids towards dipterous insect in Goiânia, it was found that A. notula was attracted to Sarcophagula occidua Fabricius (Diptera: Sarcophagidae); Neralsia splendens (Borgmeier) (Hymenoptera: Figitidae) to Cyrtoneurina pararescita Couri (Muscidae) N. splendens to C. pararescita and S.occidua; P. egeria to $S$ occidua; S. cameroni to Brontaea debilis Williston (Diptera: Muscidae); Spalangia drosophilae (Ashmead) (Hymenoptera: Pteromalidae) to B. debilis, Brontaea quadristigma (Thomson) (Diptera: Muscidae) and Palaeosepsis spp. (Diptera: Sepsidae) and Spalangia nigra (Hymenoptera: Pteromalidae) (Curtis) to B. debilis (X2 = 47.28; GL = 8; $\mathrm{P}<0.05)$ (Marchiori et al. 2013).

\section{Study 21}

The objective of this study was to understand the main species of parasitoids of frugivorous flies in southern Goiás and west Minas Gerais, Brazil. The study was conducted at the farm in Santa Therese in this region west of Minas Gerais (MG). In southern Goiás (GO) Brazil. The experiment was conducted at the farm of the Faculty of Agronomy. Each week the carrabolla and cherry fruits collected were deposited on a $5 \mathrm{~cm}$ layer of fine sand, in plastic containers, cylindrical, transparent, and open at the top. The openings of the containers were sealed after placing the fruit with organza secured with elastic to prevent the entry of other insects (Marchiori 219).

Weekly substrate pupae were separated by flotation bucket with water removed with the aid of a sieve, dried, counted and packaged in glass bottles with fine sand kept at room temperature until the emergence of the flies and/or their parasites. The collections were made in southern Goiás of September 1998 to January 1999 and west of Minas Gerais of November 2001 to January 2002 (Marchiori 2019).

A total of 304 Anastrepha spp. obtained 45 specimens of parasitoids in western Minas Gerais and 870 Anastrepha spp. were obtained. 48 specimens of parasitoids in southern Goiás. Trichopria Anastrepha Costa Lima (Hymenoptera: Diapriidae) was the species most collected in western Minas Gerais with $44.0 \%$. Doryctobracon 
areolatus (Szépligeti,) (Hymenoptera: Braconidae) was the most collected species in southern Goiás with $89.6 \%$. Regarding the total percentage of parasitism west region of Minas Gerais was $14.8 \%$ and southern Goiás $5.5 \%$. Probably related to the low synanthropy of the species of dipterans and parasitoids collected in the southern region of Goiás studied the locality is now surrounded by human populations on all sides. Trichopria anastrephae Lima showed most percentage of parasitism in western Minas Gerais of $6.6 \%$ in southern Goiás was $D$. areolatus with $5.0 \%$. T. anastrephae was obtained from Anastrepha fraterculus (Wiedemann) (Diptera: Tephritidae) in guavas, with a parasitism rate of 5.8\% (Marchiori 2019).

\section{Study 22.}

The objective was to identify species of Chalcididae (Hymenoptera: Chalcidoidea) collected in the savanna forests and pastures in Itumbiara County, State of Goias, Central Brazil using yellow pan traps. The experiment was carried out at the Agronomy College Farm, located near the Paranaiba River shore, $5 \mathrm{~km}$ from downtown Itumbiara County, State of Goias, Central of Brazil. The farm has approximately 12 alqueires. The sampling area had 1.5 alqueires constituted of ciliary forest along the Paranaiba River, gradating to mesophytic semi-deciduous forest and savanna. The area had a background of selective deforestation and forest burning and was circled by sugar cane cropping and pastures. The samplings were conducted Moericke traps 10 traps randomly placed at the soil level, totaling five traps in the pasture and five traps in the woods for each sampling (Marchiori et al. 2003).

In the 520 samplings performed during the period of January to December 1998, 121 specimens of Chalcididae from five different genera and 25 different species were collected. From these individuals $73.6 \%$ were collected in the pastures and $26.4 \%$ in the forests. The Chalcididae fauna in the pastures and forest were similar between each other at the $92.0 \%$ level. Among the Chalcididae specimens collected, the species most frequently found was Haltichella sp.4 (15,7\%), followed by Conura sp.1 (13,2\%) (Marchiori et al. 2003).

\section{CONCLUSION}

Currently, Brazil has many laboratories that work with biological control contributing to several programs of great success, mainly in the control of insect pests. Several recent works have questioned the safety of classical biological control and, specifically, the use of generalist natural enemies. There are many examples of introductions that have resulted in severe impacts on untargeted organisms, extinctions, biodiversity loss and imbalance of native communities

\section{REFERENCES}

[1] Costa A (2019) Instituto Jurumi. www.institutojurumi.org.br/2019/05/5-curiosidades-quevoce-deveria-saber.html.

[2] Gibb T (2015) In Contemporary Insect Diagnostics.1st ed. Oxford: Academic Press is an imprint of Elsevier.

[3] Marchiori CH (2014) Hymenoptera parasitoids collected in southern of Goiás and western of Minas Gerais, Brazil. Journal Pensee 76: 357-361.

[4] Marchiori CH, Penteado-Dias, AM (2002) Braconidae (Hymenoptera: Ichneumonoidea) Collected in a Native Forest Area in Itumbiara, Goiás, Brazil. Neotropical Entomology 31(4): 647-649.

[5] Marchiori CH, Silva CG, Caldas ER, Almeida KGS, Carvalho AS, Penteado-Dias AM Diaz NB, Gallardo FA (2001) Parasitóides da subfamily Eucoilinae (Hymenoptera: Cynipoidea: Figitidae) coletados em um remanescente de mata de cerrado em Itumbiara, GO. Arquivos do Instituto Biológico 68(1): 65-67.

[6] Morais AB, Perre P, Sobzaq JF (2011) Fauna de vespas parasitoides Insecta, Hymenoptera) coletadas em um fragmento de cerrado, Jataí, Goiás. X Congresso de Ecologia do Brasil. São Lourenco, MG.

[7] Souza L, Braga SMP, Campos MJO, Campos (2006) Himenópteros parasitóides (Insecta: Hymenoptera) em área agrícola de Rio Claro, SP, Brasil. Arquivos do Instituto Biológico 73(4): 465-469.

[8] Rocha JB, Veloso R, Naves RVN, Ferreira GA (2001) Características e entomofauna associada aos frutos do bacupari. Pesquisa Agropecuária Tropical 31(1): 47-54.

[9] Júnior ALM, Júnior AIC, Raizel CBE, Lira NLTA, Pereira PRV, Lau D, Moresco ER, Sobrinho SJ (2021) Levantamento de espécies de afídeos e parasitoides associadas à cultura do trigo no cerrado mineiro. http://www.alice.cnptia.embrapa.br/alice/handle/doc/10645 68.

[10] Perioto NW, Lara RIR, Costa VA (2009) Parasitic wasps (Hymenoptera) associated with fruits of Ilex affinis Gardner (Aquifoliacea) in Brazil with description of two new Chalcidoidea. Arquivo do Instituto Biológico 76(1): 85-90.

[11] Pádua DG, Zampieron SLM (2012) Inventário da Fauna de Hymenoptera Parasitóides Coletados com Redes de Varredura em um Fragmento da Serra da Babilônia, no Sudoeste do Estado de Minas Gerais. EntomoBrasilis 5(3): 211-216.

[12] Pádua DG, Zampieron SLM, Nunes JF (2014) Composition of the Families of Parasitoids Wasp in the Parque Nacional da Serra da Canastra, Minas Gerais, Brazil. EntomoBrasilis 7(3): 199-206.

[13] Souza-Filho, MFA Raga, AA, Azevedo-Filho JAB, Strikis PCC, Guimarães JAD, Zucchi RA (2009) Diversity and seasonality of fruit flies (Diptera: Tephritidae and Lonchaeidae) and their parasitoids (Hymenoptera: Braconidae and Figitidae) in orchards of guava, loquat and peach. Brazilian Journal of Biology 69(1): 31-40.

[14] Marchiori CH (2021) Parasitoids Collected in Poultry Farms in Brazil. European Journal of Biology and Biotechnology 2(3): 39-40. 
[15] Marchiori CH (2019) Parasitoids of Fly collected in urban area in Brazil. Annals of Marine Science 3(1): 11-12.

[16] Figueiredo MLC, Martins-Dias, AMP, Cruz I (2006) Associação entre inimigos naturais e Spodoptera frugiperda (Smith, 1797) (Lepidoptera: Noctuidae) na cultura do milho. Revista Brasileira de Milho e Sorgo 5(3): 340-350.

[17] Silva TM, Zampieron SLM (2016) Interações entre parasitoides e insetos endófagos em frutos de Stryphnodendron adstringens (Mart.) Coville (Fabaceae) no Cerrado Mineiro. Revista Agrogeoambiental 8(2): 5363.

[18] Santos IM, Lima VP, Soares EKS, Paula M, Calado DC (2018) Insect galls in three species of Copaifera $L$. (Leguminosae, Caesalpinioideae) occurring sympatrically in a Cerrado area (Bahia, Brazil) parasitoidism is very high, and sampling for cecidomyiids adults has been unsuccessful. Biota Neotropica 18(1): e20170356.

[19] Azevedo FR, Araújo EL, Santos IS, Moreno NBC, Pereira MLL, Azevedo R A, Alves ACL (2018) Fruit flies and parasitoids associated with guava in Barbalha, Ceará, Brazil. Revista Brasileira de Ciências Agrária 3(4): 55-86.

[20] Silva MES, Wochner MA, Sousa MSM, Barreto MR, Adaime R (2019) Moscas-das-frutas (Diptera: Tephritidae), suas plantas hospedeiras e parasitoides (HYMENOPTERA: Braconidae). Nativa Sinope 7(5): 513-519.

[21] Marchiori CH (2014) Gnathopleura semirufa (Hymenoptera: Braconidae (Brullé, 1846) parasitoid of dipterous synanthropic in Southern Goiás, Brazil. Annals of West University of Timisoara, ser. Biology 17: 9-12.

[22] Marchiori CH, Borges LMF, Ferreira LL. (2013) Dipterous parasitoids collected from cattle dung in Goiânia, central Goiás, Brazil. Pensee Journal 75(9): 418-426.

[23] Marchiori CH (2019) Parasitoids of fruit flies collected in Brazil. Qeios 12: 1-8. [24] Marchiori CH, Penteado-Dias AM, Tavares MT (2003) Parasitoids of the family Chalcididae collected in pastures and forests using yellow traps, in Itumbiara, Goiás, Brazil. Brazilian Journal of Biology 63: $357-360$. 